\title{
Relationship between body functions and referral to rehabilitation post-stroke
}

\author{
Relação entre funções do corpo e encaminhamento \\ à reabilitação no pós-AVE
}

Eleazar Marinho de Freitas Lucena, Kátia Suely Queiroz Silva Ribeiro, Ronei Marcos de Moraes, Robson da Fonseca Neves, Geraldo Eduardo Guedes de Brito, Renata Newman Leite Cardoso dos Santos*

Universidade Federal da Paraíba (UFPB), João pessoa, PB, Brazil

\begin{abstract}
Introduction: Stroke has a high prevalence in the world's population and a significant impact on those affected. Objective: To determine the relationship between body functions evaluated according to the International Classification of Functioning, Disability and Health (ICF) parameters and the referral of poststroke subjects to rehabilitation services in the city of João Pessoa-PB. Methods: This study was an observational cross-sectional study involving patients diagnosed with stroke who were affected for less than 60 months and linked to the Family Health Strategy (Estratégia de Saúde da Família - ESF). The ICF stroke core sets that identify disabilities in the body function dimension were used to construct the research instrument. Access to rehabilitation was explored using a questionnaire developed from a literature review. The statistical method of logistic regression was used to identify the disabilities in body functions that were relevant to the referral of the post-stroke subject for rehabilitation. Results: The functions that were significant ( $\mathrm{p}<0.05$ ) were functions relating to muscle tone $(\mathrm{OR}=2.38)$, functions relating to voluntary movement control $(\mathrm{OR}=2.60)$, emotional functions $(\mathrm{OR}=2.22)$, and sexual functions $(\mathrm{OR}=3.92)$. Conclusion: The findings of this study indicate that the presence of disability in these functions is associated with the referral of chronic phase post-stroke subjects to rehabilitation. Therefore, rehabilitation services should be organized to meet the specific requirements of treatment of the sequelae caused by stroke.
\end{abstract}

Keywords: Stroke. Health Services accessibility. International Classification of Functioning. Disability and Health. Regression Analysis.

\footnotetext{
* EMFL: Doctoral Student, e-mail: eleazar_lucena@hotmail.com KSQSR: PhD, e-mail: katiaqsribeiro@yahoo.com.br RMM: PhD, e-mail: ronei@de.ufpb.br RFN: MS, e-mail: robsonfisioba@gmail.com GEGB: MS, e-mail: dudugjf@yahoo.com.br RNLCS: MS, e-mail: renatanewman@hotmail.com
} 
Resumo

Introdução: O Acidente Vascular Encefálico (AVE) possui alta prevalência na população mundial e ocasiona impactos importantes aos acometidos. Objetivo: Verificar a relação da deficiência em funções do corpo avaliadas conforme parâmetros da Classificação Internacional de Funcionalidade, Incapacidade e Saúde (CIF) e o encaminhamento de sujeitos pós-AVE para os serviços de reabilitação no município de João Pessoa-PB. Métodos: Trata-se de um estudo observacional de corte transversal, envolvendo indivíduos com diagnóstico de AVE, com tempo de acometimento inferior a 60 meses e vinculados à Estratégia de Saúde da Família (ESF). Para compor o instrumento dessa investigação, utilizaram-se itens do core sets da CIF para o AVE, para identificar deficiências na dimensão funções do corpo. Investigou-se o acesso à reabilitação por meio de um questionário elaborado a partir da revisão da literatura. Utilizou-se o método estatístico de regressão logística para identificar as deficiências nas funções do corpo que foram relevantes para encaminhar o sujeito pós-AVE à reabilitação. Resultados: As funções que apresentaram significância estatística (p-valor <0,05) foram: funções relacionadas ao tônus muscular (OR =2,38); funções relacionadas ao controle dos movimentos voluntários $(O R=2,60)$; funções emocionais (OR =2,22); e funções sexuais $(O R=3,92)$. Conclusão: Os achados deste estudo apontam que a presença de deficiência nessas funções está associada com o encaminhamento de sujeitos pós-AVE em fase crônica para a reabilitação. Portanto, devem-se organizar os serviços de reabilitação para atender às especificidades do tratamento das sequelas provocadas pelo AVE.

Palavras-chave: Acidente Cerebrovascular. Acesso aos Serviços de Saúde. Classificação Internacional de Funcionalidade. Incapacidade e Saúde. Análise de Regressão.

\section{Introduction}

Stroke is a pathological entity with a high prevalence and has a severe impact on several dimensions of the affected individual's life, both in developed and developing countries (1). Stroke can occur at any age, but the incidence is higher and doubles every decade after 65 years of age (2).

Currently, morbidity and mortality due to stroke are major public health problems in Brazil and other Latin American countries because stroke prevention and the provision for appropriate treatment that can minimize disabilities represent a challenge (3). Two-thirds of the deaths from stroke occur in low and middle income countries (1). According to the Ministry of Health, there were 141,479 hospitalizations for strokes in Brazil in 2014. The southeast region had the highest percentage (42.94\%), followed by the northeast with $27.72 \%$. Among the states in the northeast, Paraíba ranked seventh in the number of hospitalizations with 4.4\%; a total of $44 \%$ of that number was concentrated in the city of João Pessoa (4).

Generally, stroke survivors face a number of new problems, such as a lack of awareness of the severity of the impairment and its consequences, fear of the disease worsening, change in socioeconomic status and the need for care and information regarding their health condition. In more severe cases, the consequences of stroke can result in multiple disabilities, such as depressive symptoms, impaired cognition, low mobility and low capacity for self-care (5).

In this regard, Euzébio and Rabinovich (6) have highlighted the need for the referral of patients affected by cerebrovascular diseases including stroke to rehabilitation services. These referrals require the involvement of different professional nuclei in the rehabilitation team (i.e., neurologists, physical therapists, occupational therapists, nurses, speech therapists, nutritionists, psychologists, and social workers).

In the city of João Pessoa, Unified Health System (Sistema Único de Saúde - SUS) users access rehabilitation services via referral by the Family Health Team doctor to a medical expert who is a professional in the municipal health network. Based on a clinical evaluation, the specialist prescribes a referral for the patient for rehabilitation treatment. Depending on the treatment area, the appointment can occur in two ways: through spontaneous demand, with the user attending the treatment center itself, or via the Municipal Department of Health's vacancy regulation service. In both situations, the individual must wait for a vacancy to become available (7).

Scheper et al. (8) noted that although there was some degree of functional recovery after stroke, most individuals suffered chronic consequences that resulted in disabilities in various dimensions of functionality. 
Therefore, there is a need to adopt effective evaluation strategies to establish the functional profile and facilitate the development of appropriate rehabilitation strategies (9).

The absence of parameters justifying the organization of the supply of rehabilitation services is believed to have negative consequences for individuals with stroke sequelae and for the public health system, such as difficulty of access, increased unmet demands for treatment, service overload, delayed start of treatment, and consequent worsening of the patient's functional status. Therefore, it maybe argued that health service referral data can provide information that may improve the organization and efficiency of these services in providing care.

In this context, the objective of this study was to determine the association of body function disabilities evaluated according to the "body function" dimension of the International Classification of Functioning, Disability and Health (ICF) stroke core sets with the referral of stroke-affected subjects to rehabilitation services in the city of João Pessoa-Paraíba.

\section{Methods}

This study was a quantitative study involving field research with a cross-sectional design. It included a sampling grid of 152 individuals diagnosed with stroke with a period of 60 months or less since onset. The subjects were over 18 years of age, of both genders and registered in the area covered by the Family Health Teams/Units (Equipes/Unidades de Saúde da Família USFs) that made up the 5 Health Districts (Distritos Sanitários - DS) in the city of João Pessoa.

The sampling grid was constructed from lists provided by the Municipal Health Department and totaled 324 subjects of both genders linked to the USFs and affected by stroke during the period between 2006 and 2010. The sample size was determined using the formula $\mathrm{n}=\mathrm{Z2} \mathrm{PQ} / \mathrm{d} 2$, where $\mathrm{n}=$ the minimum sample size, $\mathrm{Z}=$ the reduced variable, $\mathrm{P}=$ the probability of finding the studied phenomenon, $\mathrm{Q}=1-\mathrm{P}$, and $\mathrm{d}=$ the desired accuracy. $P=50 \%$ was adopted because it was a multi-dimensional evaluation and the desired accuracy for the study was $10 \%$. Based on this criterion, the minimum sample calculated was 147 subjects.

We decided to evaluate the body functions of strokeaffected users due to their intimate connection with physical disabilities and their resulting need to seek rehabilitation services. The body function dimension of the ICF was used because it provided parameters to measure the degree of disability (10). The body function items contained in the stroke core sets were used to form the research instrument. The term core sets refers to essential items in surveying a particular health condition (11). Additionally, a questionnaire was used that was developed by the researchers and that contained items covering access to rehabilitation, such as receipt of referral, receipt of treatment and continuity of treatment until the time of study participation. Personal identification, clinical and sociodemographic information was also included.

For the purposes of this study, "referrals to rehabilitation" were considered to be instructions received by the users to obtain the following care modes: physical therapy, psychology, speech therapy and occupational therapy. All of these modalities were grouped into a single dichotomous variable (referred or not referred to rehabilitation).

The description of the disability related to body functions was confronted with the need or not for rehabilitation. Two possible outcomes for the post-stroke subject were established: referral to rehabilitation or no such referral.

Data were collected between August 2010 and November 2011 during a visit to the study participant's home environment. In cases where the subjects had cognitive impairment and/or a speech deficit, the data were obtained from the caregiver or other proxy informant. Cognitive impairment was evaluated using the Mini Mental State Exam (MMSE), in which the educational level was considered when measuring the person's ability to answer a questionnaire; a score of 18 or more is required by a literate individual and 13 points or more by an illiterate individual (12) to exclude cognitive impairment. The exclusion criterion was the presence of major disabilities prior to the stroke episodes.

The data were initially tabulated in a spreadsheet (Microsoft Office Excel 2007) and later transferred to a statistical package (R software version 2.14.1). The statistical method of logistic regression was used to identify the disabilities in body functions that were relevant to the referral of the post-stroke subject for rehabilitation.

The variables investigated in the inferential analysis had a dichotomous nature and were classified as dependent ("referral to rehabilitation") and independent (disability in the body functions as follows: 
"consciousness functions"; "orientation functions"; "attention functions"; "memory functions"; "emotional functions"; "perception functions"; "mental language functions"; "vision functions"; "auditory functions"; "vestibular functions"; "proprioceptive functions"; "tactile function"; "feeling of pain"; "defecation functions"; "urinary functions"; "sexual functions"; "functions relating to joint stability"; "functions relating to muscle strength"; "functions relating to muscle tone"; "involuntary movement reflex functions"; and "functions relating to voluntary control").

Because there were many variables in this study, a simple logistic regression model was constructed for each one to pre-select those that might form part of the final model. At this stage, a less judicious significance level of $20 \%$ was adopted because this was a screening process. A $5 \%$ significance level was adopted to fit the final model.

The Research Ethics Committee of the Health Sciences Center, Federal University of Paraíba (Universidade Federal da Paraíba - UFPB), approved the project under Protocol no. 430/09. Participants signed a consent form authorizing the performance of the study and the publication of the results. The participants' autonomy was respected and their anonymity guaranteed by ensuring their privacy regarding confidential data.

\section{Results}

Table 1 describes the general characteristics of the sample, which comprised 152 subjects distributed evenly between genders. As shown, there was a predominance of respondents living in a stable union and aged over 60 years, with a mean age of 65.95 years.

Concerning stroke characteristics, ischemic was the most prevalent (40.8\%), but a large percentage of the subjects could not identify the type suffered (44.7\%). Most identified only one stroke episode in the five years prior to the interview, with the episode occurring more than 12 months prior. The mean time since onset was 26.74 months, which indicated a sample of individuals in the chronic phase of the disease.

Concerning access to rehabilitation services, $69.7 \%$ of subjects revealed that they had undergone rehabilitation after the stroke. However, $48 \%$ of the sample did not receive referrals to the service, and only $22.4 \%$ received treatment during the period surveyed.
Table 1 - General characteristics of the sample $(n=152)$ Joao Pessoa, 2011-2012

\begin{tabular}{|c|c|c|}
\hline CHARACTERISTIC & $n$ & $\%$ \\
\hline \multicolumn{3}{|l|}{ Gender } \\
\hline Female & 79 & 52.0 \\
\hline Male & 73 & 48.0 \\
\hline \multicolumn{3}{|l|}{ Age group } \\
\hline 60 years or more & 108 & 71.0 \\
\hline $25-59$ years & 44 & 28.9 \\
\hline \multicolumn{3}{|l|}{ Civil status } \\
\hline Stable relationship & 99 & 65.1 \\
\hline Widow/er & 29 & 19.1 \\
\hline Separated & 13 & 8.6 \\
\hline Single & 11 & 7.2 \\
\hline \multicolumn{3}{|l|}{ Stroke type } \\
\hline Did not know & 68 & 44.7 \\
\hline Ischemic & 62 & 40.8 \\
\hline Hemorrhagic & 22 & 14.5 \\
\hline \multicolumn{3}{|l|}{ Time since onset } \\
\hline 13 months or more & 107 & 70.4 \\
\hline Up to 12 months & 45 & 29.6 \\
\hline \multicolumn{3}{|c|}{ No. of events in the past 5 years } \\
\hline 1 & 98 & 64.5 \\
\hline 2 or more & 54 & 35.5 \\
\hline \multicolumn{3}{|c|}{ Referral to rehabilitation } \\
\hline Yes & 79 & 52.0 \\
\hline No & 73 & 48.0 \\
\hline \multicolumn{3}{|c|}{ Access to rehabilitation } \\
\hline Yes & 106 & 69.7 \\
\hline No & 46 & 30.3 \\
\hline \multicolumn{3}{|c|}{ Under treatment at time of interview } \\
\hline Yes & 34 & 22.4 \\
\hline No & 118 & 77.6 \\
\hline
\end{tabular}

Table 2 shows the impairment in the "ICF body function" dimensions. All body functions investigated showed some degree of impairment among the sample subjects. Notably, the most affected functions were vestibular functions (71\%), emotional functions (68.4\%), memory functions (67.8\%), muscle strength (66.4\%), attention functions (59.9\%), functions related to muscle tone (55.9\%), perception functions (52.6\%), awareness functions (52\%), and pain sensation (50.0\%). 
Table 2 - Prevalence of impairment in body functions

\begin{tabular}{|c|c|c|}
\hline BODY FUNCTION & $n$ & $\%$ \\
\hline Vestibular functions & 109 & 71.7 \\
\hline Emotional functions & 104 & 68.4 \\
\hline Memory functions & 103 & 67.8 \\
\hline Muscle strength & 101 & 66.4 \\
\hline Attention functions & 91 & 59.9 \\
\hline Functions relating to muscle tone & 85 & 55.9 \\
\hline Perception functions & 80 & 52.6 \\
\hline Consciousness functions & 79 & 52.0 \\
\hline Pain sensation & 76 & 50.0 \\
\hline Functions relating to voluntary movement control & 62 & 40.8 \\
\hline Vision functions & 61 & 40.4 \\
\hline Tactile functions & 59 & 38.8 \\
\hline Mental language functions & 59 & 38.8 \\
\hline Proprioceptive functions & 56 & 36.8 \\
\hline Defecation functions & 53 & 34.9 \\
\hline Orientation functions & 52 & 34.2 \\
\hline Functions relating to joint stability & 46 & 30.3 \\
\hline Functions relating to involuntary movement reflexes & 45 & 29.6 \\
\hline Sexual functions & 44 & 28.9 \\
\hline Urinary functions & 41 & 27.0 \\
\hline Auditory functions & 31 & 20.4 \\
\hline
\end{tabular}

Table 3 shows the distribution of the prevalence of disability in body functions according to the referral to rehabilitation. The body functions for which most subjects had a disability and were referred to rehabilitation were consciousness functions (32.2\%), attention functions (32.2\%), emotional functions (41.4\%), perception functions $(31.6 \%)$, vestibular functions (37.5\%), pain sensation (28.3\%), muscle strength (37.5\%), and functions related to muscle tone (36.8\%). There was a number of affected individuals with some disability caused by stroke in all body functions who did not receive a referral to rehabilitation. Among the subjects who were not referred to a rehabilitation service, memory functions, attention functions, vestibular functions and muscle strength were the most prevalent in terms of the presence of disabilities.

A simple logistic regression model was developed for each body function for pre-selection to establish the final adjusted model. Variables that were significant $(\mathrm{p}<$ 0.2 ) were included in the final model. However, it should be emphasized that the body functions that were not included in the subsequent model fitting stages were also relevant for evaluation and intervention in the rehabilitation process. 
Table 3 - Referral to rehabilitation and prevalence of body function disabilities

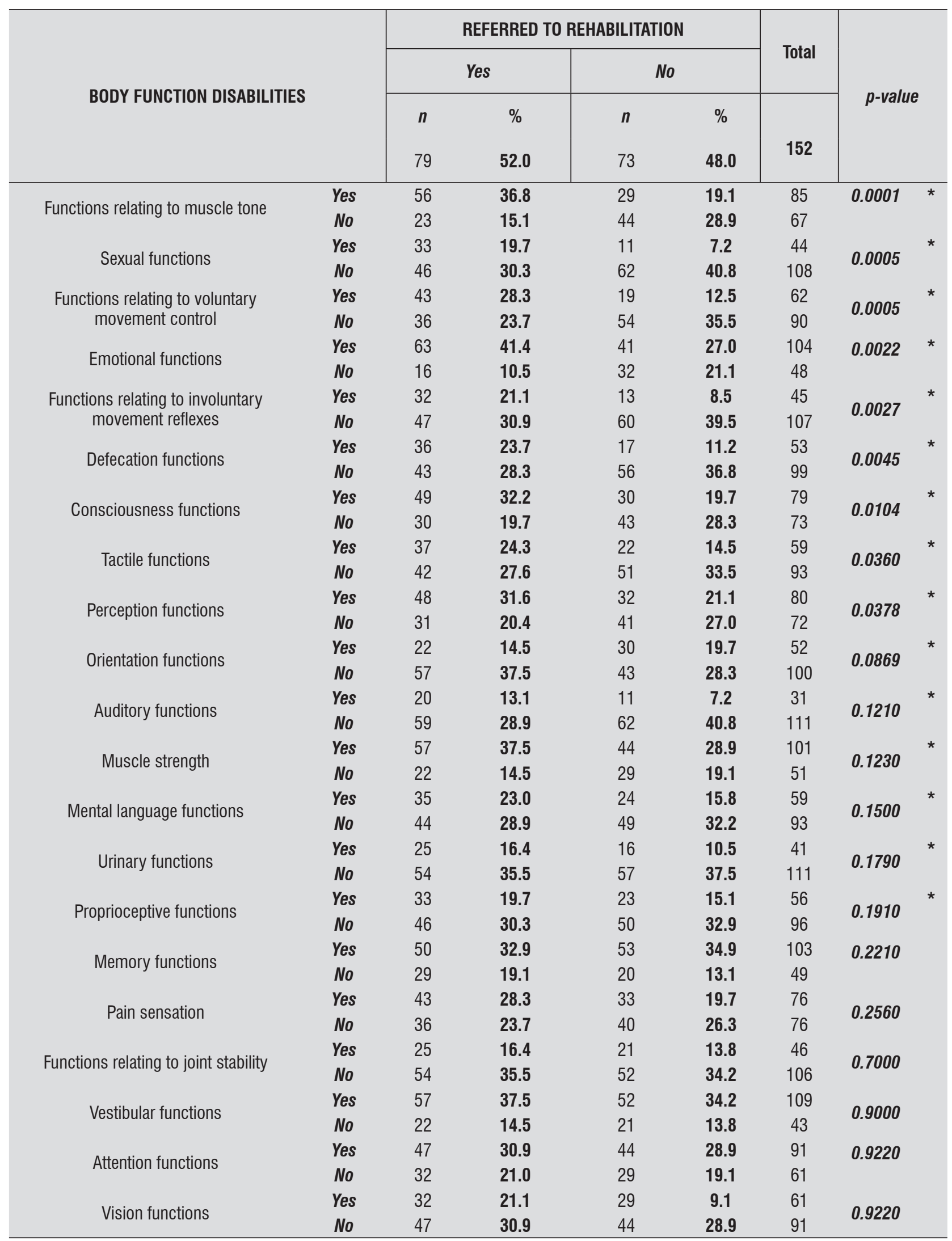

Note: * $p$-value $<0.2$. 
The final logistic regression model was fit by considering a more judicious significance level of $5 \%$. The variables that were significant $(\mathrm{p}<0.05)$ were functions relating to muscle tone, functions relating to voluntary movement control, emotional functions, and sexual functions (Table 4).

Table 4 - Significant variables in the final model

\begin{tabular}{|c|c|c|c|}
\hline VARIABLE & $\begin{array}{l}\text { ESTIMATED } \\
\text { PARAMETER }\end{array}$ & \multicolumn{2}{|c|}{$p$-value } \\
\hline Intercept & -1.6929 & $3.04 e-05$ & ** \\
\hline $\begin{array}{l}\text { Disability in functions } \\
\text { relating to muscle tone }\end{array}$ & 0.8662 & 0.0278 & ** \\
\hline $\begin{array}{l}\text { Disability in functions } \\
\text { relating to voluntary } \\
\text { movement control }\end{array}$ & 0.9554 & 0.0178 & ** \\
\hline $\begin{array}{l}\text { Disability in emotional } \\
\text { functions }\end{array}$ & 0.8000 & 0.0464 & $\star \star$ \\
\hline $\begin{array}{l}\text { Disability in sexual } \\
\text { functions }\end{array}$ & 1.3659 & 0.0018 & ** \\
\hline
\end{tabular}

Note: ${ }^{* *}$ p-value $<0.05$.

After structuring a logistic regression model, it is necessary to evaluate the accuracy of the estimates. The process operates according to a measure of discrepancy or goodness of fit. In this study, we used the deviance $(D)$ function, which measures the discrepancy between the saturated model (best possible model) and the research model. The model was considered adequate because the $D$ statistic related to the adjusted logistic regression model (173.2188) was less than the reference Chi-square value (176.2938) with 147 degrees of freedom.

Logistic regression analysis enables estimation of the natural logarithm $(I n)$ of the odds ratio (OR) for all of the model's independent variables, thereby allowing direct estimation via parameter exponentiation. The results of the odds ratio calculation for the model variables in relation to the study outcome are shown in Table 5. Interpretation of the odds ratio of the final logistic regression model variables is useful for verification of the effect of each variable on the possibility of the stroke patient being referred for rehabilitation. This analysis facilitates recognition of the profiles of patients referred to rehabilitation services in the city of João Pessoa.
Table 5 - ODDS RATIO (OR)

\begin{tabular}{c|c|c|c}
\hline VARIABLE & OR & EFFECT & INTENSITY \\
\hline $\begin{array}{c}\text { Disability in functions } \\
\text { relating to muscle tone }\end{array}$ & 2.3779290 & INCREASES & 2.38 \\
$\begin{array}{c}\text { Disability in functions } \\
\text { relating to voluntary } \\
\text { movement control }\end{array}$ & 2.5997659 & INCREASES & 2.60 \\
$\begin{array}{c}\text { Disability in emotional } \\
\text { functions }\end{array}$ & 2.2255838 & INCREASES & 2.22 \\
$\begin{array}{c}\text { Disability in sexual } \\
\text { functions }\end{array}$ & 3.9193096 & INCREASES & 3.92 \\
\hline
\end{tabular}

\section{Discussion}

The sample studied enjoyed a high level of access to rehabilitation services, particularly in relation to initial entry into the service. However, the same situation did not occur regarding the continuation of treatment because most individuals were not in treatment at the time of participation in this study despite having the evaluated body function disabilities.

Concerning the functionality domain, the logistic regression model presented in this study showed a relationship between referral to rehabilitation and the functional capacity motor dimension that was represented by disability in functions relating to muscle tone and functions relating to the control of voluntary movements. By analyzing the isolated effect of each of these functions on the study's response variable, we observed a 2.38 and 2.60 -fold increased probability of referral of the patient to rehabilitation for individuals with disabilities in functions relating to muscle tone and the control of voluntary movements, respectively. When organizing rehabilitation services, it is extremely important to emphasize this dimension to attend to the patient's motor function issues therapeutically.

Pavan et al. (13) found that $62 \%$ of participants had some motor disability; of these, $35 \%$ did not undergo rehabilitation treatment due to difficulty of access or lack of referral to a specialized rehabilitation center. According to Nunes, Pereira and Silva (14), the motor function of stroke patients progressed satisfactorily after rehabilitation; delaying the start of treatment had a negative effect on this function and hence on the patient's functionality. This effect may arise during hospitalization or after discharge, when many patients 
await treatment on extensive public health service waiting lists.

Motor function disability presents as hemiplegia or hemiparesis of the hemibody contralateral to the lesion in the cerebral hemisphere. The clinical picture of motor dysfunction includes muscle weakness, change of tone, associated reactions, loss of balance reactions, straightening and protection and loss of selective movement, which can hamper the patient's ability to perform functional movements with the trunk and limbs (15). A study that investigated muscle deficiencies in post-stroke patients found the presence of hemiparesis in $80 \%$ of survivors, with a predominance of motor sequelae such as difficulty in motor control, spasticity, stiffness and pain, which are impairments that determine major functional limitations (16).

Physical therapy plays a key role in treating these patients and makes use of various resources that can make muscle tone more functional to promote motor recovery and prevent secondary complications (17). Dietz and Sinkjaer (18) stressed the importance of motor rehabilitation through physical therapy protocols to promote the recovery of motor ability, thereby preventing secondary complications. Therefore, it is fundamentally important to ensure the access of this population segment to rehabilitation services.

Regarding emotional functions in post-stroke patients, the sample subjects demonstrated a high prevalence of disability in this dimension. The decision to refer the patient to the rehabilitation service showed statistical significance, with an $\mathrm{OR}=2.22$. Because stroke causes neuromuscular and cognitive changes, impairment in functional performance has a very large negative impact on personal, family and social relationships and harms the quality of life of patients and their families (19).

According to Terroni et al. (20), psycho-emotional complications can be seen as determinants of the loss of functionality in individual with stroke sequelae. Brito and Rabinovich (21) highlighted the effects of depression as a secondary complication of stroke; depression resulted in longer hospital stays, greater functional and cognitive deficits, limitations in activities of daily living, a decreased life span and a decline in functionality in the absence of rehabilitation after hospital discharge compared with individuals who were not depressed. A study by Tanaka and Scheicher (22) that investigated the relationship between depression and postural imbalance in elderly people who had suffered strokes found a high prevalence of depression in patients with chronic stroke; this situation was associated with disability.

Psychological care in rehabilitation deals directly with the individual's neuropsychological behavior and is meant to provide information on affective-emotional functions and to accomplish family dynamics (23). The onset of a depressive episode after a stroke may be prevented by performing a care intervention developed by a psychologist. A study on post-stroke depression found that this complication was prevalent in the first quarter after impairment by the disease, with $41 \%$ of patients receiving specialized treatment; the prevalence was $54 \%$ in the group of patients without treatment (24).

The results of the present study indicated that impairment in sexual functions was significantly associated with the patient's post-stroke referral to rehabilitation. In isolation, this variable showed the greatest influence on the response variable, with patients with disabilities in sexual functions being 3.92 times more likely to be referred to rehabilitation. This finding suggests the need to organize health services to provide specific attention to the treatment of the sexual dimension of functionality in patients who have suffered strokes along with a broader look at this issue by health management and all rehabilitation team professionals.

Concerning marital relationships in particular, a very large burden is placed on the spouse, which leads her/ him to absorb much of the emotional state of the sick companion, such as feelings of disappointment, dependency, lack of confidence, worthlessness and loneliness (25). In this context, sexuality becomes a complicated issue to be discussed between the couple experiencing the negative effects of the disease. The literature indicates that $85 \%$ of spouses do not usually engage in sexual relations following the occurrence of a stroke $(26,27)$.

The disability in sexual functions due to a stroke highlights the importance of rehabilitation in improving the patient's sex life because sexuality is a dimension that is very important to a person's quality of life (28). In the field of physical therapy, various strategies are used in the treatment of sexual dysfunction, such as the use of kinesio therapy, biofeedback, electrotherapy and guidance on pelvic anatomy and sexual dysfunction $(29,30)$.

The general characteristics of the study sample have been discussed in more detail in other studies $(31,32)$. However, it should be emphasized that the results indicate the need for the inclusion and participation of individuals affected by stroke in support activities and/ or rehabilitation services. This strategy will maintain the health of and develop functionality in these patients. 


\section{Conclusion}

Given the current situation regarding the organization of rehabilitation services for stroke patients in the city of João Pessoa, great difficulties related to supply and accessibility for these users are observed when the modalities of physiotherapy, psychology, speech therapy and occupational therapy are analyzed as a whole. Planning measures that provide solutions to structure these services are important to provide equity in the provision of assistance. The decision models adopted here are tools capable of supporting the organization of effective and evidence-based supply.

We understand that the decision to group the methods above into a single dichotomous variable meant that inferences about the supply and accessibility of each included rehabilitation mode could not be drawn. Therefore, further studies are needed to address this issue and increase knowledge on this subject.

Furthermore, there is a need for studies covering a more homogeneous population in relation to time since stroke onset and more specific clinical pictures because this study's sample is characterized by subjects in the chronic phase of the disease in which the disabilities that are significant in the model are more prevalent.

The potential offered by the ICF, particularly tools such as the core sets, in providing more extended evaluations of the health needs of those suffering from stroke sequelae must be highlighted. The ways in which these data can be used to develop knowledge about the expansion and organization of service provision should also be further studied.

Given the chronic effects of stroke on the quality of life of the affected subjects, recognition of the relationship between disability in bodily functions and referral to rehabilitation represents a useful strategy to help services. In this sense, the findings of this study indicate that the presence of disability in functions relating to muscle tone, emotional functions, functions relating to voluntary movement control and sexual functions is associated with the referral of post-stroke subjects in the chronic phase to rehabilitation. Therefore, these services should be organized with the human and structural resources necessary to respond to these demands. To that end, it is also necessary to support management by providing information that can be used to create actions that support the user to provide more dignified and comprehensive care.

\section{References}

1. Copstein L, Fernandes JG, Bastos GAN. Prevalência e fatores de risco para AVC numa população do sul do Brasil. Arq Neuropsiquiatr. 2013;71(5):294-300.

2. Costa FA, Silva DLA, Rocha VM. Severidade clínica e funcionalidade de pacientes hemiplégicos pós-AVC agudo atendidos nos serviços públicos de fisioterapia de Natal (RN). Cienc Saude Colet. 2011;16(Supl. 1):1341-8.

3. Tosta ED, Rebello LC, Almeida SS, Neiva MSS. Tratamento do acidente vascular cerebral isquêmico com r-tPA: o desafio da implantação em um hospital terciário no Brasil. Arq Neuropsiquiatr. 2014;72(5):368-72.

4. Brasil. Ministério da Saúde. DATASUS. Informações Epidemiológicas e Morbidade. Informações de Saúde Epidemiológicas e Morbidade: Brasil. Brasília; 2014 [cited 2015 Mar 13]. Available from: http://tinyurl. com/k3nc6rd.

5. Baumann M, Le Bihan E, Chau K, Chau N. Associations between quality of life and socioeconomic factors, functional impairments and dissatisfaction with received information and home-care services among survivors living at home two years after stroke onset. BMC Neurol. 2014;14:92.

6. Euzebio CJV, Rabinovich EP. Compreendendo o cuidador familiar do paciente com sequela de Acidente Vascular Encefálico. Temas Psicol. 2006;14(1):63-79.

7. Souza ARB, Ribeiro KSQS. A Rede Assistencial em Fisioterapia no Município de João Pessoa: uma Análise a Partir das Demandas da Atenção Básica. Rev Bras Ci Saude. 2011;15(3):357-68.

8. Scheper VP, Ketela M, Van DPI, Visser-Meily JM, Lindeman E. Comparing contents of functional outcome measures in stroke rehabilitation using the international classification of functioning, disability and health. Disabil Rehabil. 2007;29(3):221-30.

9. Fernandes MB, Cabral DL, Souza RJP, Sekitani HY, Teixeira-Salmela LF, Laurentino GEC. Independência funcional de indivíduos hemiparéticos crônicos e sua relação com a fisioterapia. Fisioter Mov. 2012;25(2):333-41.

10. Organização Mundial de Saúde (OMS)/Organização Panamericana de Saúde (OPAS). CIF classificação internacional de funcionalidade, incapacidade e saúde. Universidade de São Paulo; 2003. 
11. Geyh S, Kurt T, Brockow T, Cieza A, Ewert T, Omar Z, et al. ICF Core Sets For Stroke. J Rehabil Med. 2004;44:135-41.

12. Mendes LM, Neves RF, Ribeiro KSQS, Brito GEG, Lucena EMF, Batista HRL, et al. Estado cognitivo dos usuários com AVE na atenção primária à saúde em João Pessoa PB. Acta Fisiatr. 2011;18(4):169-74.

13. Pavan K, Lianza R, Campos P, Gagliard RJ, Lianza S. Identificação de pacientes com incapacidades pós AVC no ambulatório de neurologia da Santa Casa de São Paulo do ponto de vista reabilitacional. Med Reabil. 2008;27(3):93-7.

14. Nunes S, Pereira C, Silva MG. Evolução funcional de utentes após AVC nos primeiros seis meses após a lesão. EssFisiOnline 2005;1(3):3-20.

15. Schuster RC. Correlação entre disfunções motoras e respiratórias no AVC. Rev Neurocienc. 2011;19(4):587-8.

16. Le Brausser N, Sayers S, Ouellette M, Fielding R. Muscle impairments and behavioral factors mediate functional limitations and disability following stroke. Phys Ther. 2006;86(10):1342-50.

17. Silva DD, Borges ACL, Lima MO, Lima FPS, Tatsukawa ST, Nogueira DV, et al. Resistência ao movimento e atividade eletromiográfica dos músculos flexores e extensores de cotovelo em pacientes hemiparéticos espásticos submetidos à crioterapia e estimulação elétrica neuromuscular. Rev Bras Eng Biom. 2012;28(3):248-60.

18. Dietz V, Sinkjaer T. Spastic movement disorder: impaired reflex function and altered muscle mechanics: Review. Lancet Neurol. 2007;6(8)725-33.

19. Falcão IV, Carvalho EMF, Barreto KML, Lessa FJD, Leite VMM. Acidente vascular cerebral precoce: implicações para adultos em idade produtiva atendidos pelo Sistema Único de Saúde. Rev Bras Saude Mater Infant. 2004;4(1):95-101.

20. Terroni LMN, Mattos PF, Sobreiro MFM, Guajardo VD, Fráguas-Júnior R. Depressão pós-AVC: aspectos psicológicos, neuropsicológicos, eixo HHA, correlato neuroanatômico e tratamento. Rev Psiq Clin. 2009;36(3):100-8.

21. Brito ES, Rabinovich EP. The family also becomes sick! Changes secondary to stroke occurring within families. Interface (Botucatu). 2008;12(27):783-94.
22. Tanaka AFD, Scheicher ME. Relação entre depressão e desequilíbrio postural em idosos que sofreram acidente vascular encefálico. Fisioter Mov. 2013;26(2):315-20.

23. Neves PP, Fontes SV, Fukujima MM, Matas SLA, Prado GF. Profissionais da saúde, que assistem pacientes com Acidente Vascular Cerebral, necessitam de informação especializada. Rev Neurocienc. 2004;12(4):173-81.

24. Kotila M, Numminen H, Waltimo O, Kaste M. Depression after stroke. Results of the finnstroke study. Stroke. 1998;29(2):368-72.

25. Bocchi SCM. Vivenciando a sobrecarga ao vir a ser o cuidador familiar de pessoa com Acidente Vascular Cerebral (AVC): Uma análise do conhecimento. Rev Lat Am Enfermagem. 2004;12(1):115-21.

26. Béthoux F, Calmels P, Gautheron V, Minaire P. Quality of life of the spouses of stroke patients: a preliminary study. Int J Rehabil Res. 1996;19(4):291-9.

27. Robinson-Smith G, Maboney C. Coping and marital equilibrium after stroke. J Neurosc Nurs. 1995;27(2):83-9.

28. Jung JH, Kam SC, Choi SM, Jae SU, Lee SH, Hyun JS. Sexual dysfunction in male stroke patients: Correlation between brain lesions and sexual function. Urology. 2008;71(1):99-103.

29. Moreno AL. Fisioterapia em Uroginecologia. 2nd ed. São Paulo: Manole; 2009. Portuguese.

30. Antonili RS, Simões D. Abordagem fisioterapêutica nas disfunções sexuais femininas. Rev Neurocienc. 2010;18(2):267-74.

31. Ribeiro KSQS, Neves RF, Brito GEE, Morais JD, Lucena EMF, Medeiros JM, et al. Perfil de Usuários Acometidos por Acidente Vascular Cerebral Adscritos à Estratégia Saúde da Família em uma Capital do Nordeste do Brasil. R Bras Ci Saude. 2012;16(s2):25-44.

32. Ribeiro KSQS, Neves RF, Brito GEE, Sousa KM, Lucena EMF, Batista HRL. Acesso à reabilitação no pós-AVC na cidade de João Pessoa, Paraíba. Revista Baiana Saúde Pública. 2012;36(3):699-712.

Received in 05/22/2015

Recebido em 22/05/2015

Approved in 05/16/2016

Aprovado em 16/05/2016 